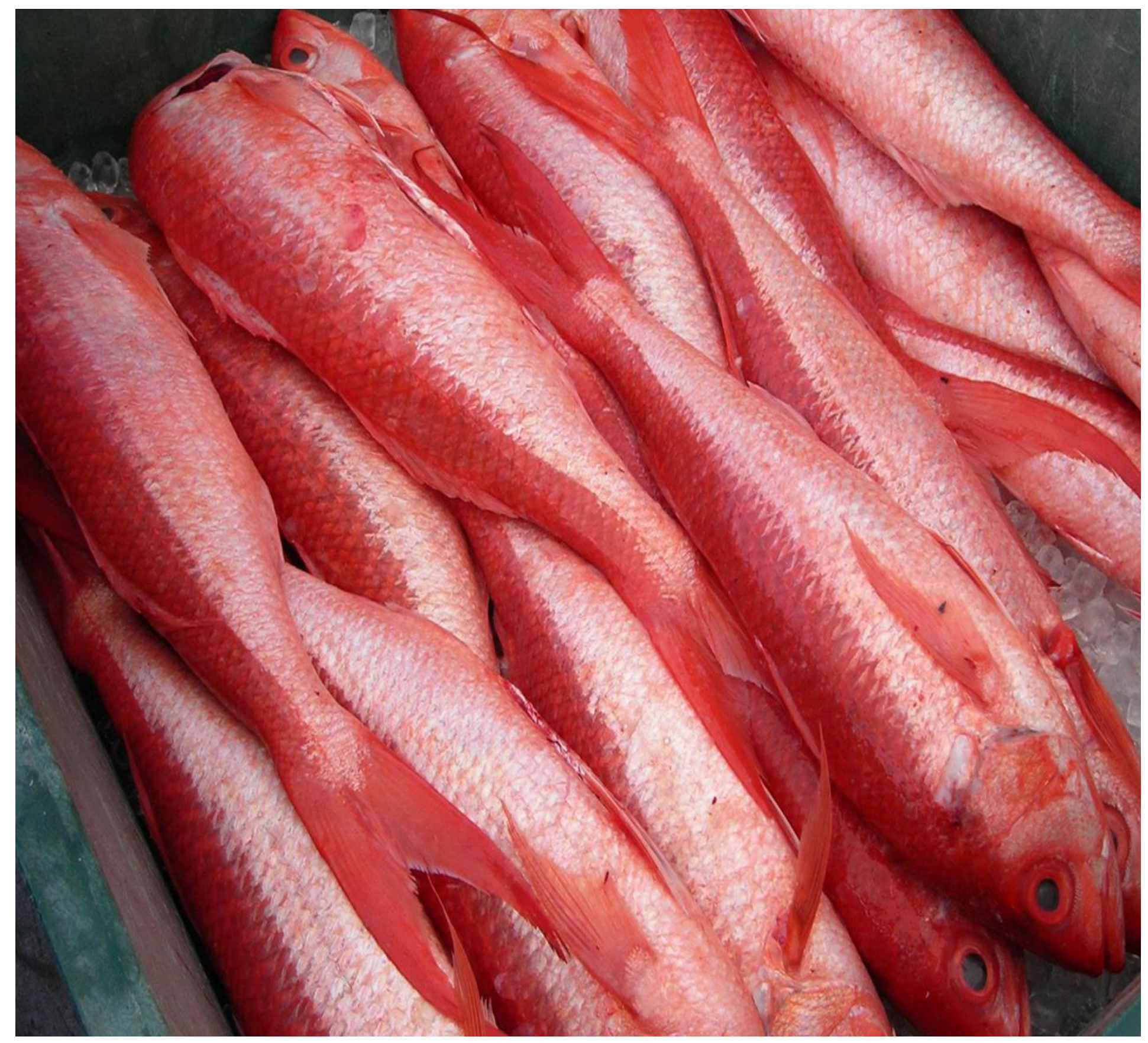

\title{
Update on the 2016-2017 catch trends in the Saba Bank fisheries
}




\section{Update on the 2016-2017 catch trends in the Saba Bank fisheries}

Author(s): $\quad$ T. Brunel, A. Kuramae, J. Odinga and A.O. Debrot

This research project was carried out by Wageningen Marine Research at the request of and with funding from the Ministry of Agriculture, Nature and Food Quality for the purposes of Policy Support Research Theme 'Caribisch Nederland'. 
Brunel. T, Kuramae, A. Odinga, J. Debrot, A. O. Update on the 2016-2017 catch trends in the Saba Bank fisheries. Wageningen marine research, Wageningen marine research report C083/18. pp.22.

Keywords: Saba Bank, fisheries, West Indian lobster, Panulirus argus, snapper.

Client:

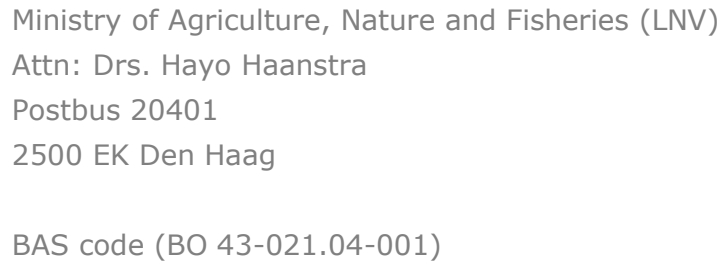

This report can be downloaded for free from https://doi.org/10.18174/464398 Wageningen Marine Research provides no printed copies of reports

IMARES Wageningen UR is ISO 9001:2015 certified.

Photo cover: Martin de Graaf

\section{(C) 2016 Wageningen Marine Research}

Wageningen Marine Research, an institute Wageningen Marine Research accepts no liability for consequential damage, nor within the legal entity Stichting Wageningenfor damage resulting from applications of the results of work or other data Research (a foundation under Dutch private obtained from Wageningen Marine Research. Client indemnifies Wageningen law) represented by Dr. M.C.Th. Scholten, Marine Research from claims of third parties in connection with this application. Managing Director All rights reserved. No part of this publication may be reproduced and / or

KvK nr. 09098104, published, photocopied or used in any other way without the written permission WMR BTW nr. NL 8113.83.696.B16.

Code BIC/SWIFT address: RABONL2U IBAN code: NL 73 RABO 0373599285 


\section{Contents}

$\begin{array}{lr}\text { Summary } & 4\end{array}$

1 Introduction $\quad \mathbf{5}$

2 Methods $\quad \mathbf{5}$

3 Results $\quad 6$

3.1 Annual landings and effort 6

3.2 Lobster Trap Fishery $\quad 8$

3.2.1 Lobster $\quad 8$

3.2.2 Mixed Reef Fish 13

$\begin{array}{lll}3.3 & \text { Redfish Fishery } & 14\end{array}$

$\begin{array}{ll}\text { 3.3.1 Trap fishery } & 14\end{array}$

$\begin{array}{llr}4 & \text { Conclusions and recommendations } & 18\end{array}$

$\begin{array}{llr}5 & \text { Acknowledgments } & 19\end{array}$

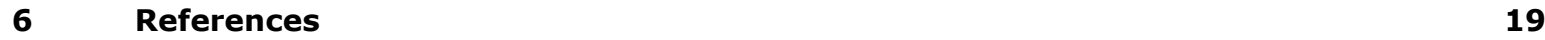

$\begin{array}{lr}\text { Quality Assurance } & 20\end{array}$

$\begin{array}{lr}\text { Justification } & 21\end{array}$ 


\section{Summary}

The recent status and trends in the of Saba Bank fisheries up to and including 2015 port sampling data have been previously reported by de Graaf et al. (2017) and a policy brief has also been written based on those results (Debrot and de Graaf (2018). The purpose of this report is to update recent catch trends in the Saba Bank fisheries with the data from 2016 and 2017.

For the lobster fishery (Panulirus argus), the number of fishing trips (and number of traps set) gradually grew from 2012 to 2015 but has since levelled off. The resulting landings of lobster have shown a similar pattern of increase up to 2015 but have now levelled off at around 70 tonnes annually. Increasing landings per unit effort indicate that the formerly reduced lobster abundance, which had been declining since 2000 and which had reached its lowest level in 2011, has subsequently increased relatively steadily all through 2017 , and now has increased back to levels close to those of 2007. The average size of lobsters taken, continues to be large, which is favourable to gradual stock recovery.

Mixed landings of reef fish in the lobster fishery have fluctuated between 10 and 20 tonnes annually. The LPUE abundance index in bycatch species also shows a decrease of about $35 \%$ from high levels in 2000 and 2007 to lowest levels in 2011, followed by an increase up to 2013, after which landings have levelled off.

In the redfish trap fishery (Lutjanus spp.), the number of trips in the redfish trap fisheries had grown significantly during the period 2012 to 2015. In 2016 effort increased again to 625 trips. In 2017 the exerted fishing effort dropped down to about 350 trips, a level seen last in 2012. The landings of redfish have fluctuated over this period, with lower values in 2012 and 2017 and higher values in 2014 and 2016. The LPUE abundance index shows a decrease by 50\% between 2007 and 2011, followed by an increase to slightly higher and constant values between 2012 and 2016, while in 2017 the LPUE abundance index continued increasing. The only snapper for which sufficient data was available, was the silk snapper, Lutjanus vivanus. Average size of the silk snappers landed continued its increasing trend, indicative of gradual stock recovery. The drop in snapper landings, despite the higher LPUE in 2017, can especially be ascribed to the 6-month closed season implemented that year (Graaf et al. 2017).

The overall conclusion is that for, both the lobster and redfish stocks, stock status, based on the LPUE index, and size-structure trends have continued in developing favourably. Bottom drop longline, pelagic and bycatch landings have remained much less important and have shown no significant new developments.

There are two matters of concern that require follow up. Firstly, the positive prognosis for the snapper "stock" status may partly be based on targeting geographically different stocks as well as different species. Hence the data as collected and analysed may actually be presenting a too optimistic assessment. To evaluate whether this is actually the case will require more detailed analysis based on individual species, as well as more accurate geographical recording of catches than as currently practiced. The second matter of concern regards the fate of the traps that were in the water on the Bank when the hurricanes Irma and Maria struck the area in September 2017. If trap loss was large, this may lead to higher detrimental impacts of ghost fishing in the coming years. 


\section{Introduction}

A first WMR report on the status and trends in Saba bank fisheries has been published in October 2017, presenting results based on data collected by WMR between 2012 and 2015 (Graaf et al., 2017). The data collection program has continued since then under the responsibility of Saba Bank Management Unit. This short report presents an updated assessment of trends in effort, landings, the LPUE index of population status (landings per unit effort) and size-structure of the landings, now including data from 2012 to 2017.

\section{Methods}

For general information on the fishery as well as all methods of data collection, catch and effort estimation and standardization of LPUE we refer to Graaf et al. (2017) who followed basic standard methods as outlined by the FAO (Stamatopoulos 2002). Figure 1 shows a map of the bank and the geographical quadrants for which fisheries data were recorded.

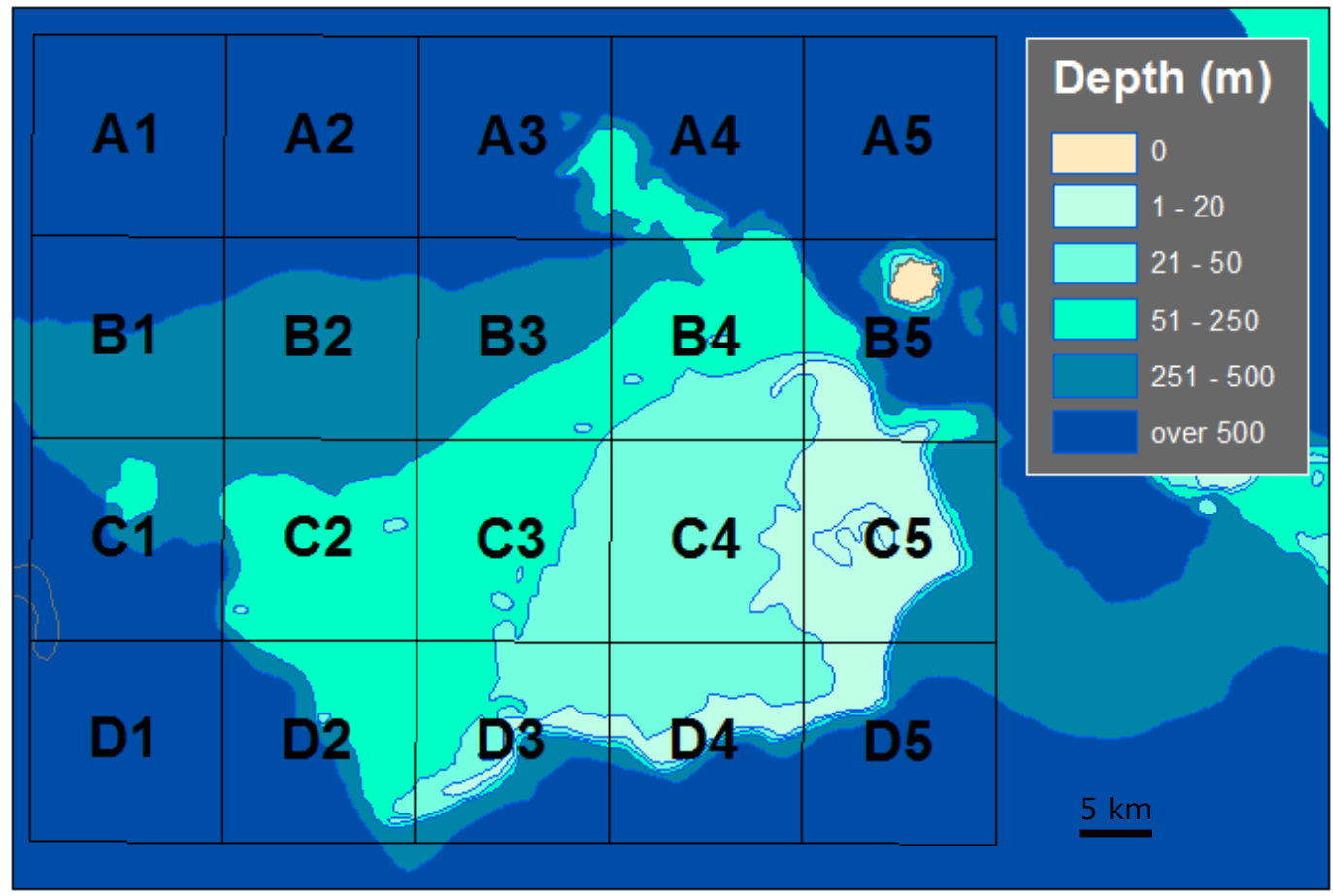

Figure 1: Overview of the study area with the 20 sub-areas used in the fishery monitoring scheme. (The depth zones in this map are inaccurate and require updating). 


\section{Results}

\subsection{Annual landings and effort}

The data show an increase in the number of fishing trips using lobster traps from roughly 600 days in 2012 (for around 50000 trap drops) to 900 days in 2015 (74000 trap drops) and values around 850 fishing days (66 000 trap drops) since then (Figure $2 a$ and Table 1). The landings of lobster have also increased from 2012 to 2015 years, from 37 to 76 tonnes annually, and have remain at similar levels since then (67 and 76 tonnes in 2016 and 2017). Landings of fish in the lobster traps followed a similar trend, with a doubling between 2012 and 2015, a small decrease in 2016, and an increase back to 2015 level in 2017.

The number of trips using redfish traps has also increased from 2012 to 2016 (from 340 to 623 days), and decreased sharply in 2017 (back to 2012 levels). The landings of redfish followed a similar trend. The number of trolling trips have fluctuated between 40 and 88 days, with no specific trend. The landings have fluctuated between 1.6 and 3.0 tonnes, except for 2017 for which they are estimated at around 10 tonnes (Table 1 ).

The number of trips using bottom drop longlines has been variable at between 4 and 14 days, with two year (2015 and 2017) showing much larger values (36 and 42 respectively). The total effective effort, standardized for number of hooks per day is very variable, likely reflecting both different numbers of participating vessels and differences between vessels in terms of the number of hooks per line set. Trends in the landings broadly followed the trend in the number of fishing days. 


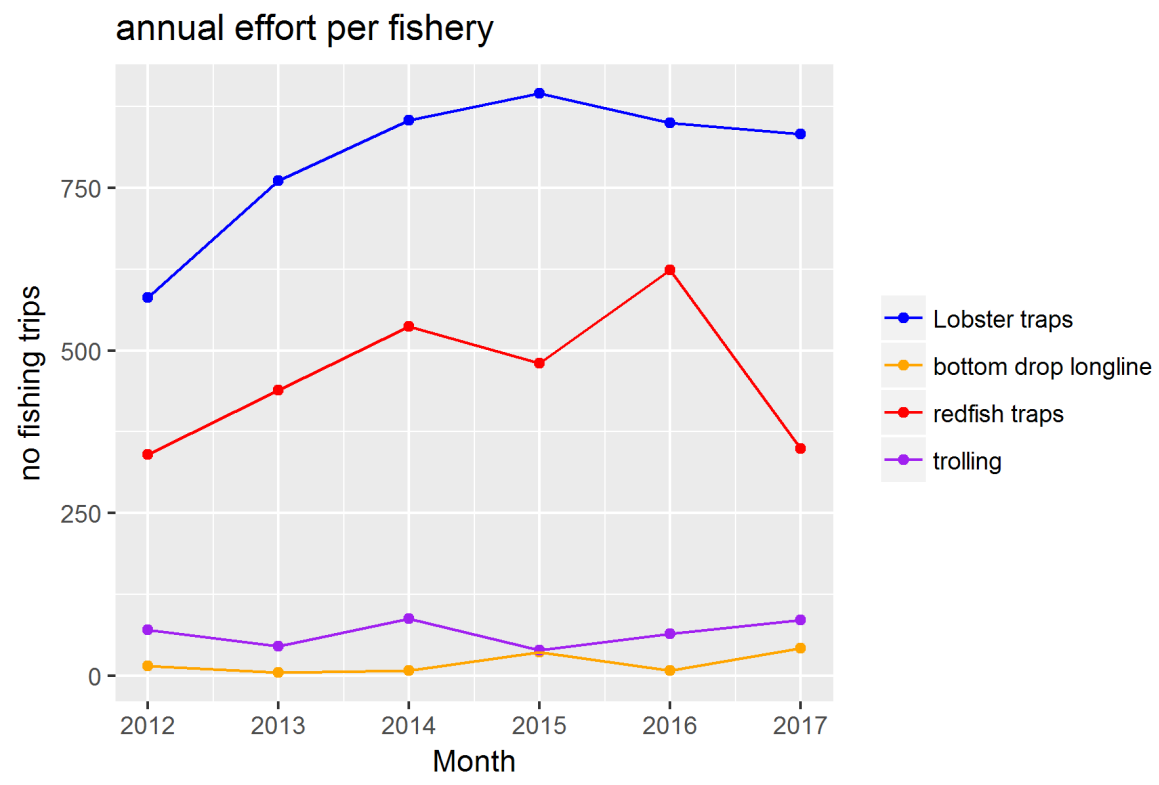

annual landings per fishery

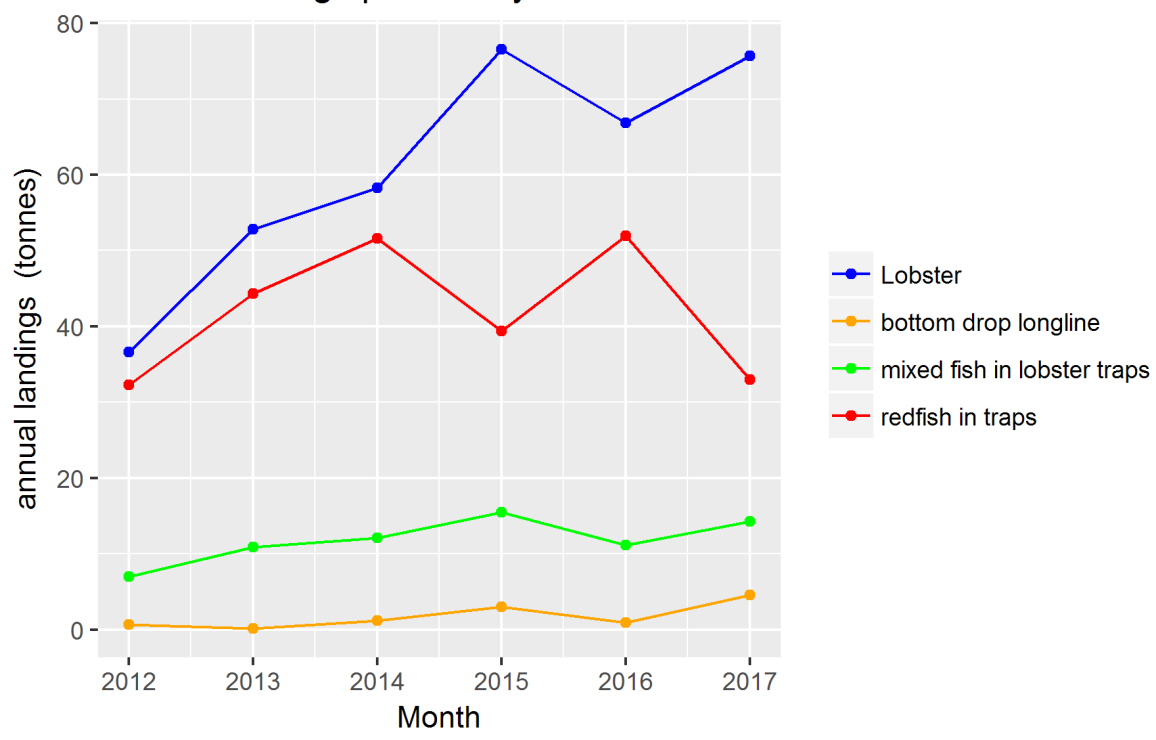

Figure 2 : annual landings per group of species (in tonnes) and fishing effort per gear in fishing days estimated from the port sampling and activity survey carried out from 2012 to 2015

Table 1: estimates of the annual effort (number of gear used and number of fishing trips) and annual landings for the year 2012 to 2015

\begin{tabular}{lrlrlr}
\hline fishery & landings & \multicolumn{3}{c}{ number of gear used } & fishing days \\
\hline $\mathbf{2 0 1 2}$ & & & & & \\
\hline Lobster trap (lobster) & 36.8 & $\mathrm{~T}$ & 48565 & traps & 596 \\
Lobster trap (mixed reef fish) & 6.6 & $\mathrm{~T}$ & 48565 & traps & 596 \\
Redfish traps (fish) & 33.0 & $\mathrm{~T}$ & 11217 & traps & 369
\end{tabular}




\begin{tabular}{|c|c|c|c|c|c|}
\hline fishery & landings & & number of gear used & & fishing days \\
\hline Bottom drop longline (fish) & 0.5 & $\mathrm{~T}$ & 1955 & hooks & 7 \\
\hline Pelagic trolling (fish) & 1.5 & $\mathrm{~T}$ & 142 & lines & 49 \\
\hline \multicolumn{6}{|l|}{2013} \\
\hline Lobster trap (lobster) & 52.8 & $\mathrm{~T}$ & 63000 & traps & 761 \\
\hline Lobster trap (mixed reef fish) & 10.9 & $\mathrm{~T}$ & 63000 & traps & 761 \\
\hline Redfish traps (fish) & 44.3 & $\mathrm{~T}$ & 13067 & traps & 439 \\
\hline Bottom drop longline (fish) & 0.1 & $\mathrm{~T}$ & 228 & hooks & 5 \\
\hline Pelagic trolling (fish) & 1.6 & $\mathrm{~T}$ & 181 & lines & 45 \\
\hline \multicolumn{6}{|l|}{2014} \\
\hline Lobster trap (lobster) & 58.3 & $\mathrm{~T}$ & 66076 & traps & 854 \\
\hline Lobster trap (mixed reef fish) & 12.1 & $\mathrm{~T}$ & 66076 & traps & 854 \\
\hline Redfish traps (fish) & 50.5 & $\mathrm{~T}$ & 15381 & traps & 537 \\
\hline Bottom drop longline (fish) & 1.2 & $\mathrm{~T}$ & 4545 & hooks & 8 \\
\hline Pelagic trolling (fish) & 2.5 & $\mathrm{~T}$ & 240 & lines & 88 \\
\hline \multicolumn{6}{|l|}{2015} \\
\hline Lobster trap (lobster) & 76.5 & $\mathrm{~T}$ & 73604 & traps & 896 \\
\hline Lobster trap (mixed reef fish) & 13.6 & $\mathrm{~T}$ & 73604 & traps & 896 \\
\hline Redfish traps (fish) & 39.1 & $\mathrm{~T}$ & 10939 & traps & 481 \\
\hline Bottom drop longline (fish) & 3.0 & $\mathrm{~T}$ & 2081 & hooks & 36 \\
\hline Pelagic trolling (fish) & 3.0 & $\mathrm{~T}$ & 107 & lines & 39 \\
\hline \multicolumn{6}{|l|}{2016} \\
\hline Lobster trap (lobster) & 66.8 & $\mathrm{~T}$ & 63474 & traps & 850 \\
\hline Lobster trap (mixed reef fish) & 11.2 & $\mathrm{~T}$ & 63474 & traps & 850 \\
\hline Redfish traps (fish) & 52.0 & $\mathrm{~T}$ & 14866 & traps & 623 \\
\hline Bottom drop longline (fish) & 0.9 & $\mathrm{~T}$ & 555 & hooks & 8 \\
\hline Pelagic trolling (fish) & 1.8 & $\mathrm{~T}$ & 417 & lines & 64 \\
\hline \multicolumn{6}{|l|}{2017} \\
\hline Lobster trap (lobster) & 75.6 & $\mathrm{~T}$ & 69732 & traps & 833 \\
\hline Lobster trap (mixed reef fish) & 14.3 & $\mathrm{~T}$ & 69732 & traps & 833 \\
\hline Redfish traps (fish) & 33.0 & $\mathrm{~T}$ & 7277 & traps & 349 \\
\hline Bottom drop longline (fish) & 4.6 & $\mathrm{~T}$ & 26284 & hooks & 42 \\
\hline Pelagic trolling (fish) & 10.3 & $\mathrm{~T}$ & 236 & lines & 86 \\
\hline
\end{tabular}

\subsection{Lobster Trap Fishery}

\subsubsection{Lobster}

\section{Landings and effort data :}

The mean number of traps set per fishing trip has been relatively stable over the period studied at around 75 traps per trip in 2000 and since 2013, with a small increase in 2007, 2011, 2012 and 2017 at around 85 traps per trip (Figure 3). Taking in consideration the annual number of trips (estimated since 2012 by the boat activity survey), the effort expressed as the annual number of traps set has increased between 2012 and 2015 from around 48000 traps/year to 73000 traps/year and remained at around 70000 in 2016 and 2017 (Table 1). 
The spatial distribution of the effort is reported accurately only since 2013 (Figure 4). The data since 2013 show that the main fishing areas are areas B4, B5 and C5 (north-eastern part of the bank, closer to the Saba island) with a slight increase of the effort on the southern part of the Bank (in areas D2 to D4) in the last 2 years. The data also show some seasonality in the distribution of the effort on the bank, with for instance a decrease of the effort in proportion on the south of the bank (D3-5) during summer.

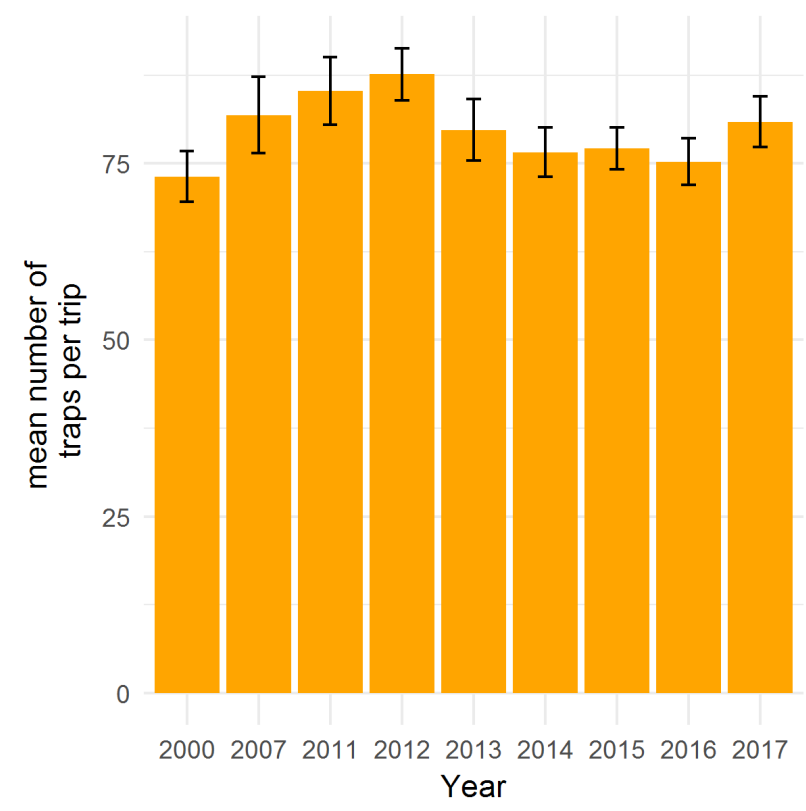

Figure 3: mean number of traps lifted per trip (with 95\% confidence intervals)
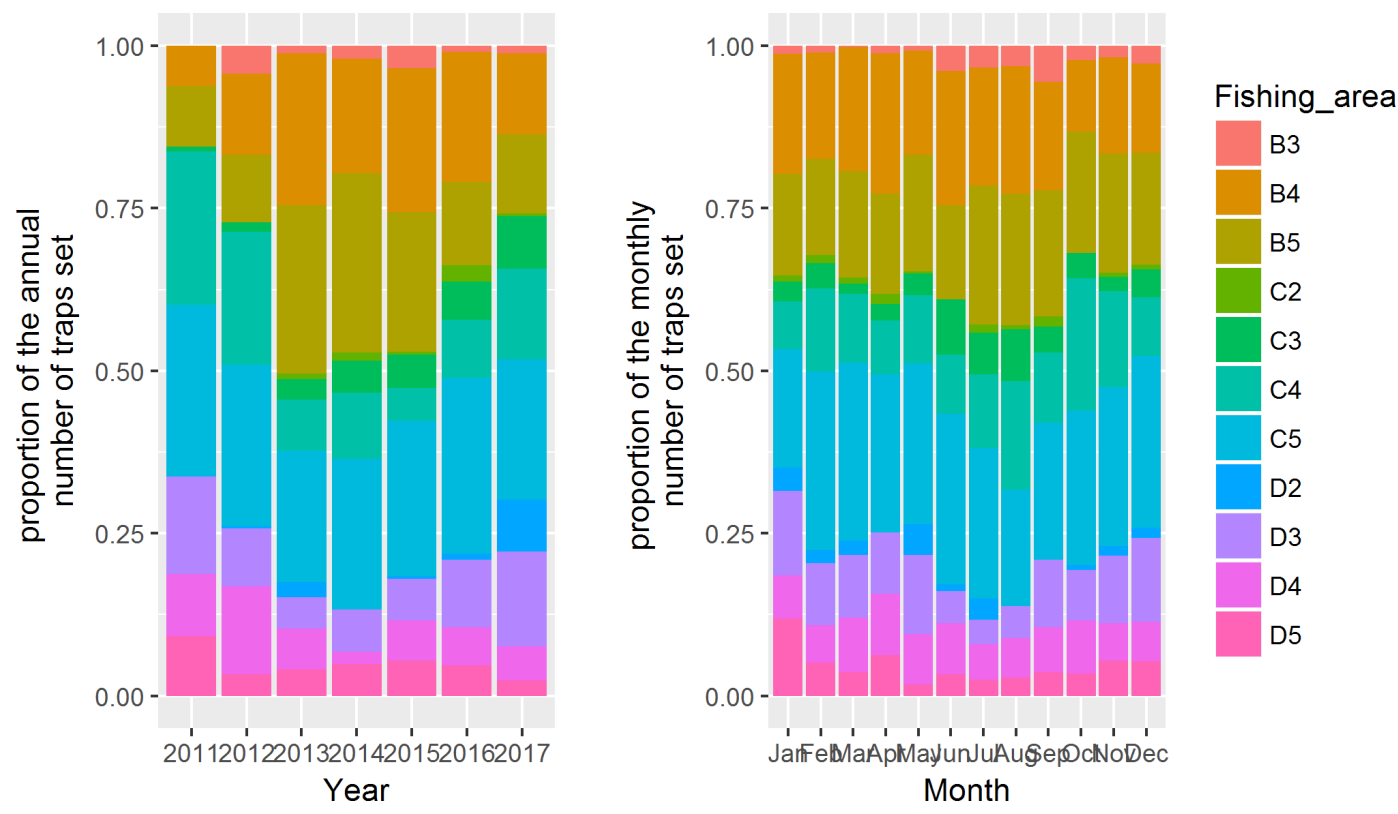

Figure 4: proportion of the annual (left) and monthly (right) effort of the lobster fishery (in total number of traps set) per fishing area.

Given the low variation of the number of traps per trip, the catch rates per trap and catch rates per trip show similar variations over the period covered by the data (Figure 5). Catch rates were substantially higher in 2000, and decreased in the 2007 and 2011 where the lowest value was observed. Catch rates have slowly increased since then, and were in 2017 close to the level of 2007. 

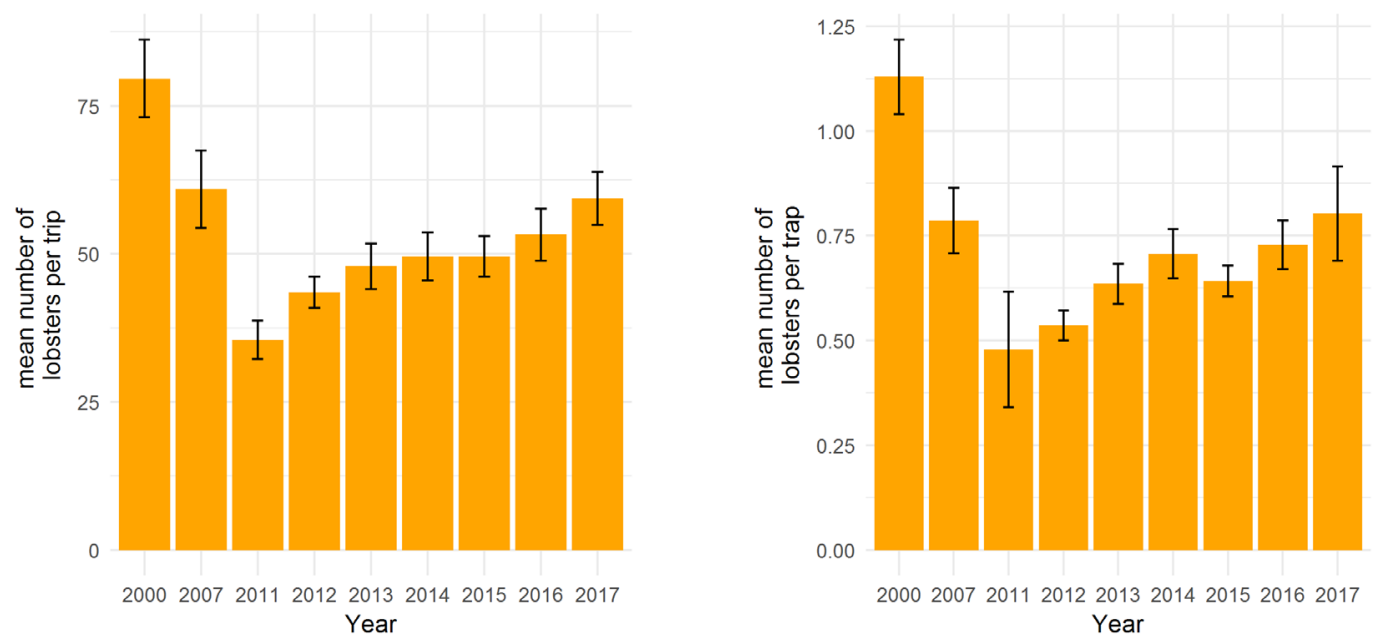

Figure 5: yearly mean number of lobster per trap and per trips (with $95 \%$ confidence intervals)

\section{CPUE standardisation using a GLM model}

All factors in the model appeared to be significant in the model fitted to the data for the years 20112017 (Table 2). For the model fitted on the data for the longer time period, all effects (month, year, trap number) were significant. The estimated effects are shown in Figure 6 . There were differences observed in the catch rates of the 5 vessels, with the most efficient vessel catching 35\% more than the less efficient one. The month effect shows the seasonality of the catch rate for a standard trip. There is a clear seasonal pattern, with highest catch rates toward the end of the year, and low catch rates during late spring/early summer. The modelled year effect is a standardised annual abundance index. It shows that the abundance dropped from higher levels in 2000 to lower levels in 2011, with a progressive increase towards the level of 2007 since then.

Table 2: significance of each model term tested by removing them one by one and comparing to the full model (GLM model of lobster catches per trip). AIC stands for Akaike information criterion (the lower the better), a p. value lower than 0.05 indicates that the effect of the corresponding factor in the model is significant.

\begin{tabular}{rrrrrr}
\hline Model term removed & $\begin{array}{r}\text { Number of } \\
\text { parameters }\end{array}$ & AIC & $\begin{array}{r}\text { Log-Likelihood } \\
\text { ratio }\end{array}$ & p. value & \\
\hline <none (full model)> & & 13288 & & & \\
factor(Year) & 6 & 13424 & 148.07 & $<2 \mathrm{e}-16$ & $* * *$ \\
factor(Month) & 11 & 13657 & 390.39 & $<2 \mathrm{e}-16$ & $* * *$ \\
factor(Boat_name) & 5 & 13524 & 245.54 & $<2 \mathrm{e}-16$ & $* * *$ \\
factor(Fishing_area) & 8 & 13312 & 39.88 & $3.37 \mathrm{E}-06$ & $* * *$ \\
logTraps & 1 & 13894 & 608.08 & $<2 \mathrm{e}-16$ & $* * *$ \\
\hline
\end{tabular}



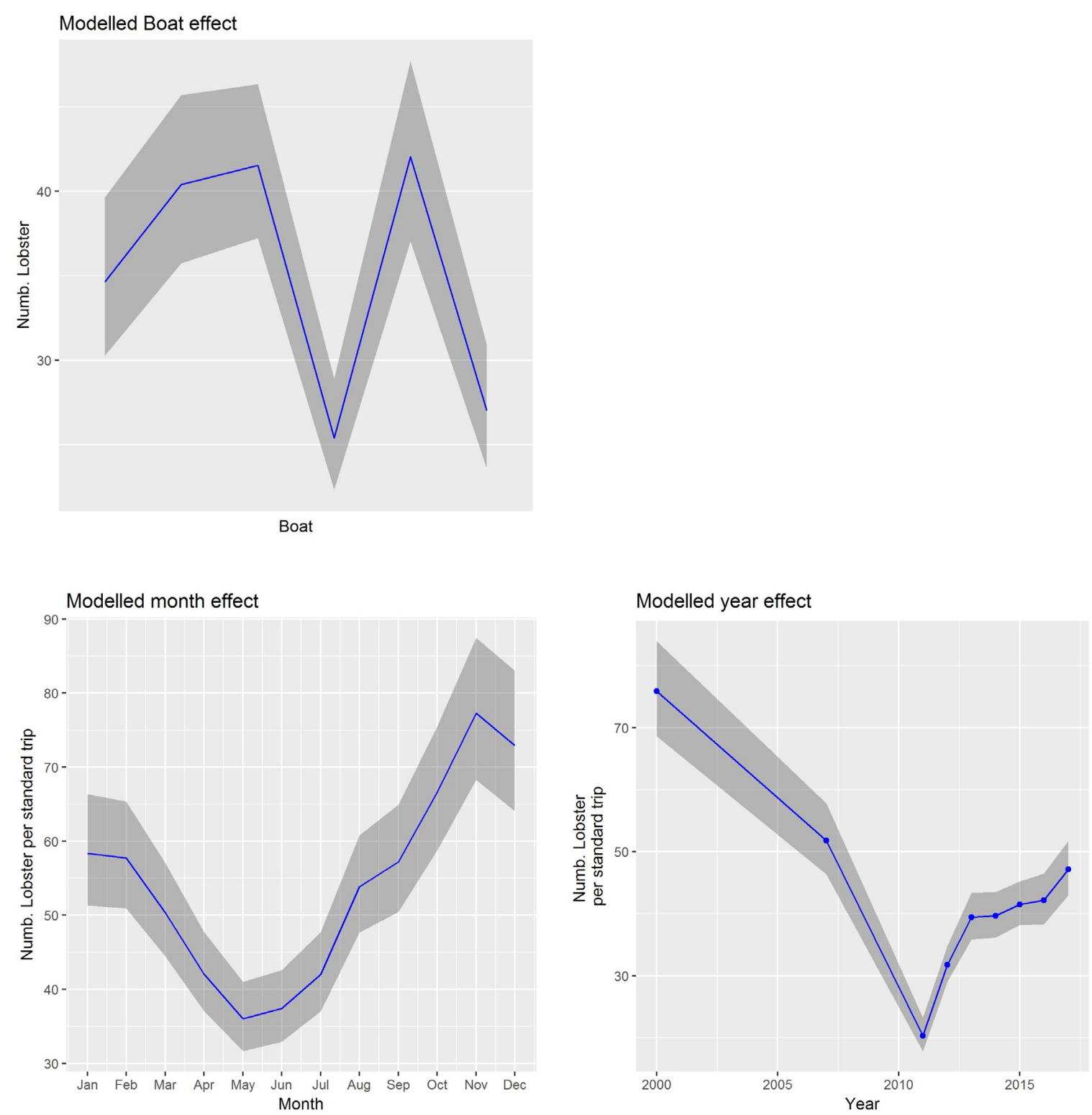

Figure 6: modelled boat effect (model fitted on the data for 2011-2015) and modelled month and year effects (model fitted on the data 2000-2015) on the catches of lobsters per trips (in numbers). blue lines represent the modelled effect (and associated uncertainty in grey).

Our overall assessment is that in the lobster fishery, the number of fishing trips (and number of traps set) gradually grew from 2012 to 2015 but has since levelled off. The resulting landings of lobster have shown a similar pattern of increase up to 2015 but have now levelled off at around 70 tonnes annually. The LPUE (landings per unit effort) abundance index indicates that the lobster abundance which had decreased by $60 \%$ from high levels in 2000 and 2007 to a very low level in 2011, have subsequently increased relatively steadily since then up to and including 2017, and now have increased back to levels close to those of 2007.

\section{Length frequency distribution of the landings}

Lobster length measurements were taken on the landings during the landing surveys conducted in the harbour at the end of a fishing trip. The size of the lobsters landed varied from 50mm (carapace length) to $200 \mathrm{~mm}$, but the bulk of the landings were between $90 \mathrm{~mm}$ and $150 \mathrm{~mm}$ (Figure 7) with a mean varying between 105 and 119mm, above the minimum landing size of 95mm. In 2000 and 2012 , the proportion of landed lobster below the minimum size were $27 \%$ and $28 \%$ respectively (up to $43 \%$ for the females), whereas in other years, this percentage was lower than $15 \%$ (Table 3 ). In recent years, the trend is towards higher mean size, and a lower proportion of undersized lobster in the landings (since 2015). 
In general the males landed were larger than the females by about $5 \mathrm{~mm}$, but the difference was particularly large in 2000 and $2011(12 \mathrm{~mm})$. The proportion of males in the landings is also higher than the females (except for 2011)

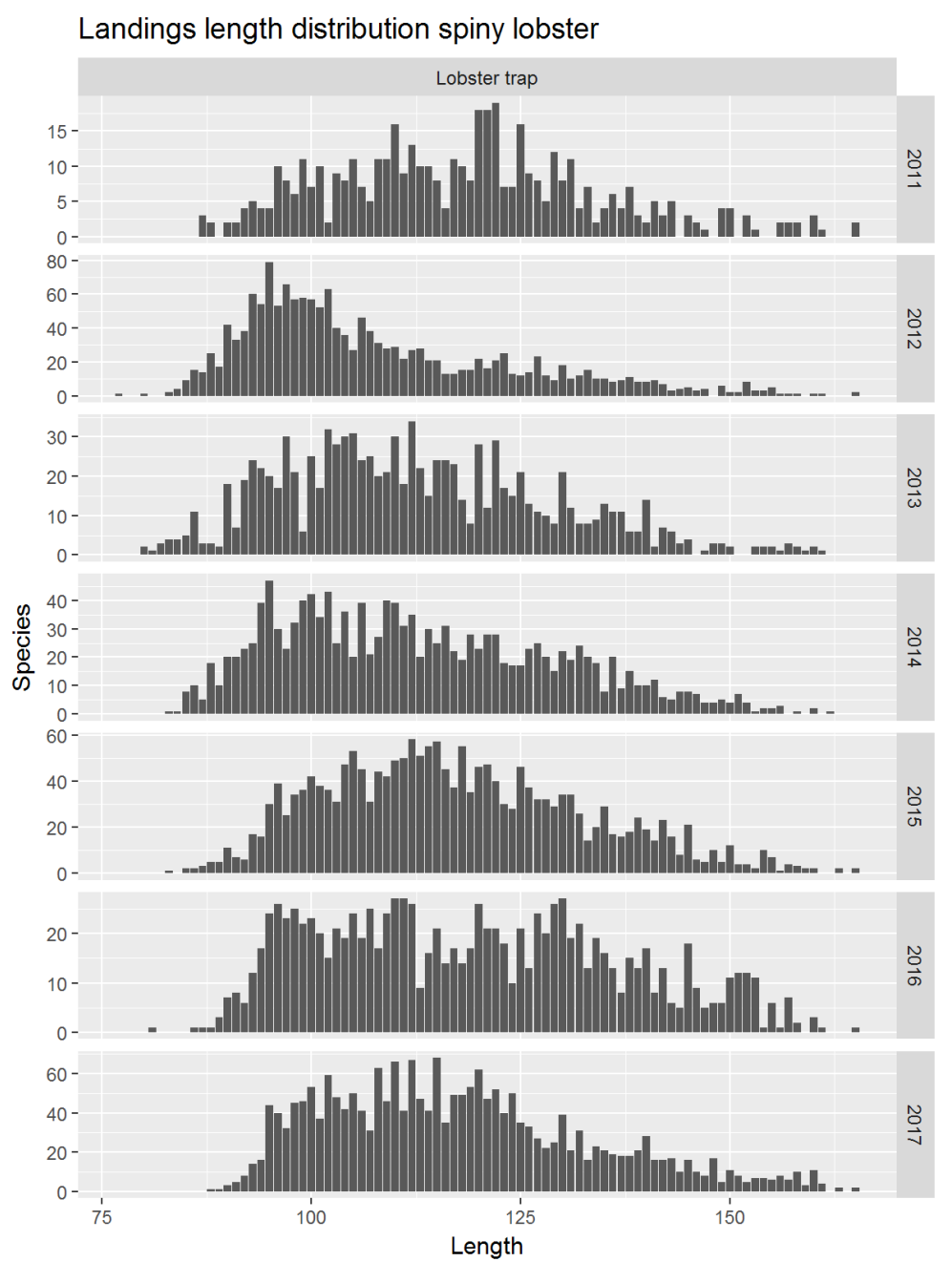

Figure 7: length frequency composition of lobster landings ( $\mathrm{mm}$ )

Table 3: lobster catches annual mean length, sex ratio and proportion of undersized individuals

\begin{tabular}{|c|c|c|c|c|c|c|c|}
\hline \multirow[b]{2}{*}{ year } & \multicolumn{3}{|c|}{ Mean length (mm) } & \multirow{2}{*}{$\begin{array}{l}\text { Sex ratio } \\
\text { (males per } \\
\text { Female) }\end{array}$} & \multicolumn{3}{|c|}{ Proportion $<95 \mathrm{~mm}$} \\
\hline & females & males & combined & & Females & Males & Combined \\
\hline 2000 & 102 & 112 & 108 & $142 \%$ & $38 \%$ & $19 \%$ & $27 \%$ \\
\hline 2007 & 111 & 114 & 113 & $164 \%$ & $19 \%$ & $12 \%$ & $15 \%$ \\
\hline 2011 & 113 & 125 & 118 & $71 \%$ & $7 \%$ & $4 \%$ & $5 \%$ \\
\hline 2012 & 103 & 107 & 105 & $123 \%$ & $43 \%$ & $15 \%$ & $28 \%$ \\
\hline 2013 & 109 & 116 & 114 & $146 \%$ & $18 \%$ & $7 \%$ & $12 \%$ \\
\hline 2014 & 110 & 115 & 113 & $156 \%$ & $19 \%$ & $9 \%$ & $13 \%$ \\
\hline 2015 & 114 & 120 & 117 & $154 \%$ & $8 \%$ & $1 \%$ & $4 \%$ \\
\hline 2016 & 115 & 122 & 119 & $194 \%$ & $8 \%$ & $4 \%$ & $6 \%$ \\
\hline 2017 & 112 & 120 & 117 & $173 \%$ & $7 \%$ & $3 \%$ & $5 \%$ \\
\hline
\end{tabular}




\subsubsection{Mixed Reef Fish}

\section{Catch and Effort data}

The temporal variations of the effort and its distribution between the different fishing area are the same as for the lobster, and show in Figures 2 and 3.

The mean catches per trap and per trip show only limited variations, with slightly higher values in the earlier years (2000 and 2007) and decrease by roughly $30 \%$ in 2011 , and stable intermediate values since 2012 (Figure 8).
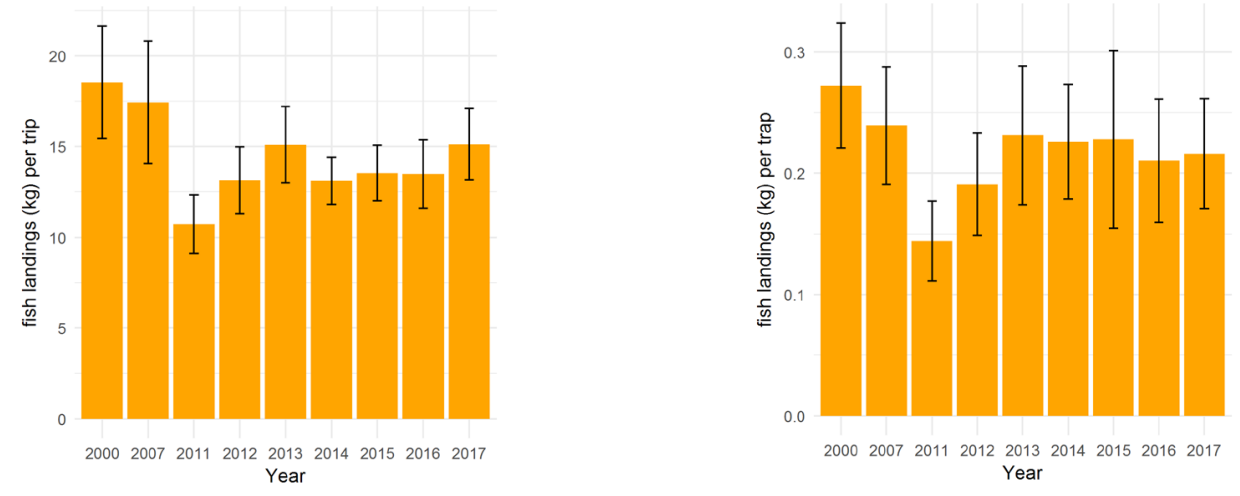

Figure 8: yearly mean catch of mixed fish $(\mathrm{kg})$ per lobster trap and per trips (with 95\% confidence intervals)

\section{GLM analyses}

The GLM model fitted on the data set covering the years 2011-2017 shows a significant effect of month, boat and trap numbers, but not for year and fishing area. The model fitted on the data set covering the years 2000-2017 showed a significant effect of year, month and trap number. Large differences were observed in the fish catch rate in lobster traps between boats (from 8 to 25 lbs for a standard trip, Figure 9). The month effect indicated higher catches from May to October. The year effect indicates a similar temporal development as the raw data with a decrease from higher levels in 2000 and 2007 to lower levels in 2011, followed by an increase in 2012 and stable levels since then.

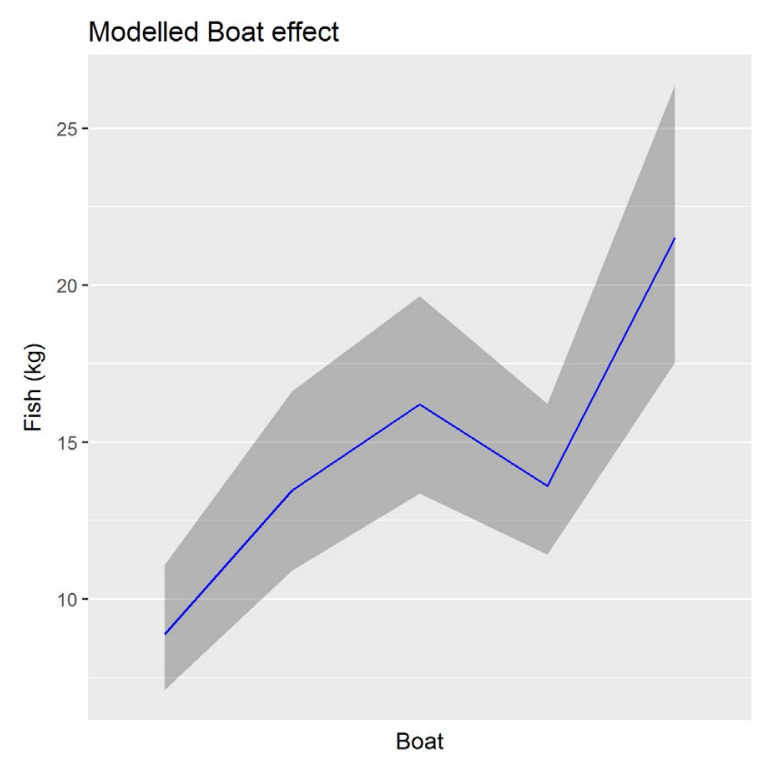



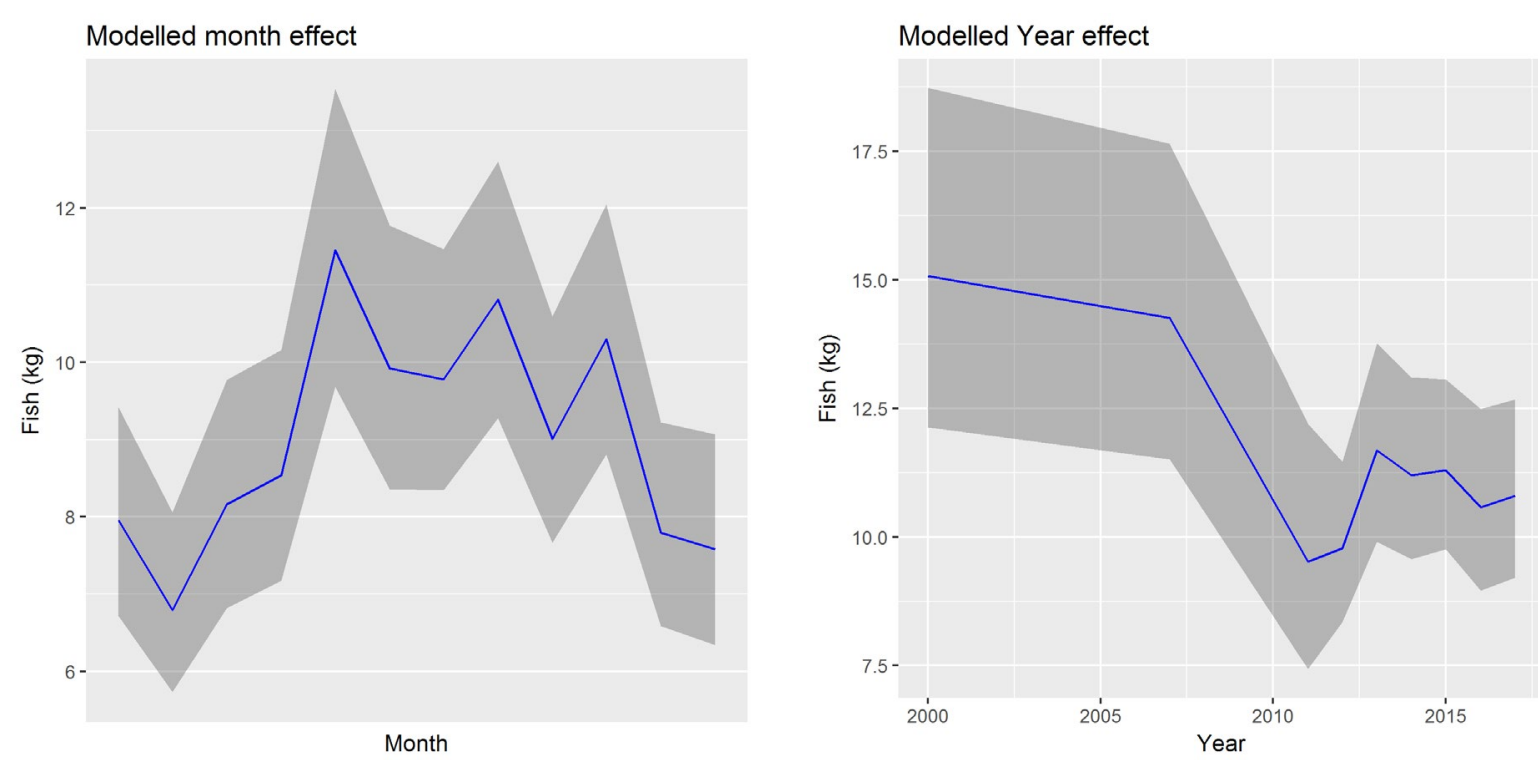

Figure 9: modelled boat effect (model fitted on the data for 2011-2017) and modelled month and year effects (model fitted on the data 2000-2017) on the catches of fish in lobster traps per trips (in numbers). blue lines represent the modelled effect (and associated uncertainty in grey).

Our overall assessment of mixed landings of reef fish in the lobster fishery have fluctuated between 10 and 20 tonnes annually. The LPUE abundance index in bycatch species also shows a decrease of about $35 \%$ from high levels in 2000 and 2007 to lowest levels in 2011, followed by a increases up to 2013, after which landings have levelled off.

\subsection{Redfish Fishery}

\subsubsection{Trap fishery}

\section{Landings and Effort data}

The average number of traps set per fishing trip has increase between 2007 and 2011, and has subsequently been decreasing from 35 to 21 between 2011 and 2017 (Figure 10).

The fishery mainly takes place in the northern part of the bank (areas B3 to B5), on the eastern border (C5) and on the deeper part of the centre-west of the bank (area C3). The spatial distribution of the effort has varied slightly over the years. Some of the years $(2012,2017)$, the effort is mainly located in the north-western part of the bank (areas B3, B4 and C3). Other years (2011, 2015, 2016), there is slightly high proportion of the trips conducted on the eastern part (C5). There has been a small increase in the depth at which the traps are set in the recent years (since 2015), which is the results of the combination of the variations in the fishing effort at large scale (i.e between areas) and at a finer scale (inside a given area). 


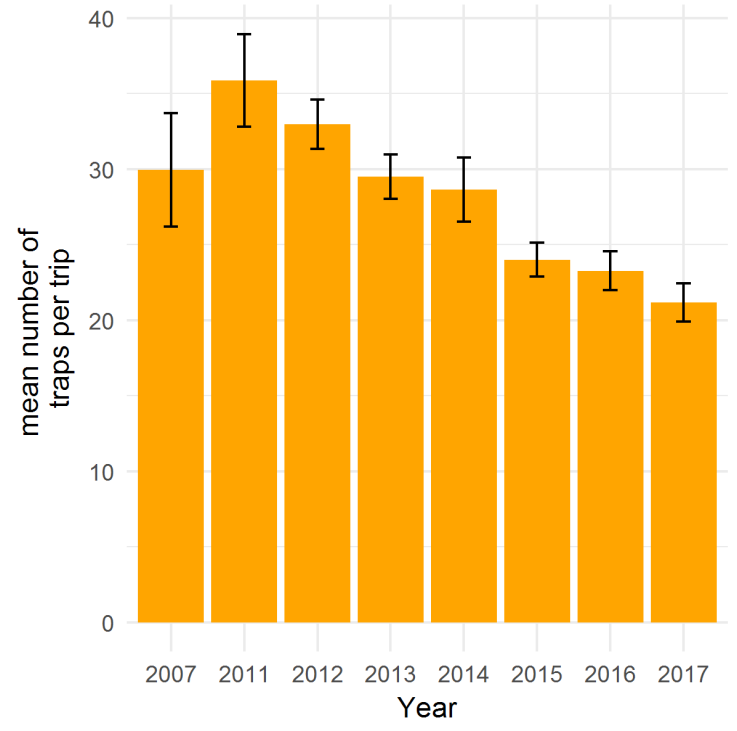

Figure 10: mean annual number of traps lifted per trips (with $95 \%$ confidence intervals)
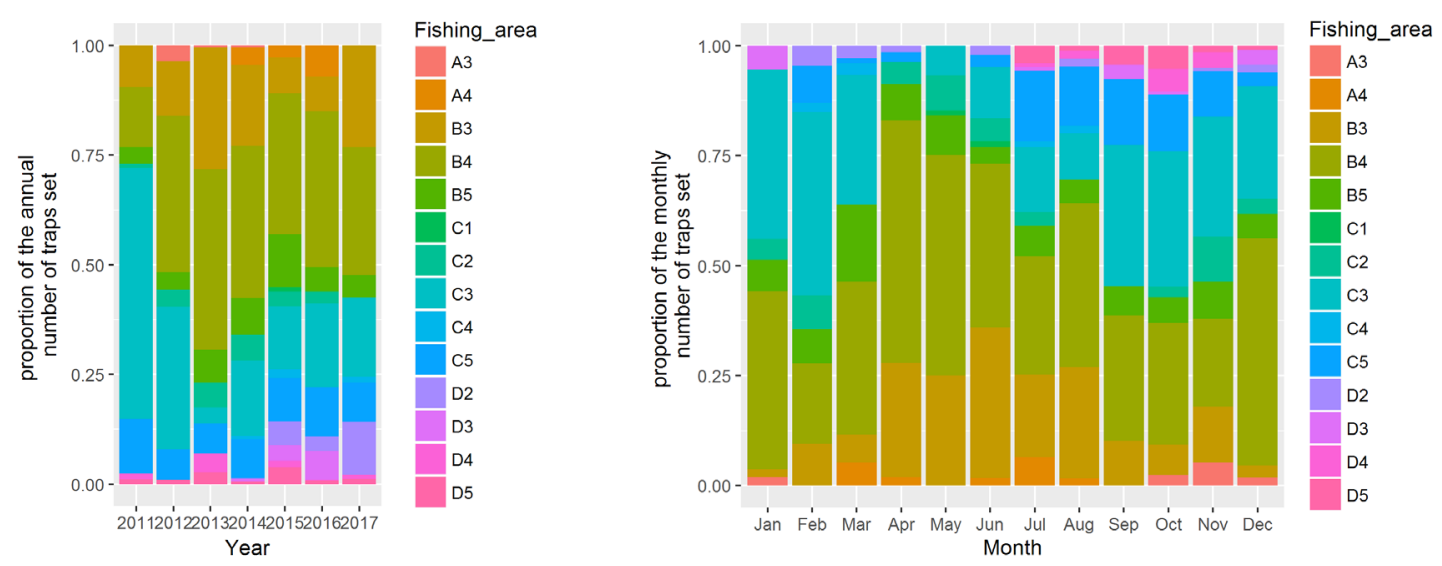

Figure 11 : proportion of the annual (left) and monthly (right) effort (in total number of traps set) per fishing area.

\section{Catch and Effort data}

The mean catches per trap and per trip indicate higher catch rates in 2007 (Figure 12). Catches per trap decreased sharply in 2011, and have been increasing since then with a particularly large increase in 2017. As a results of the decrease in the number of traps per trip (Figure 9), the catches per trips has also declined since 2012, except for 2017.
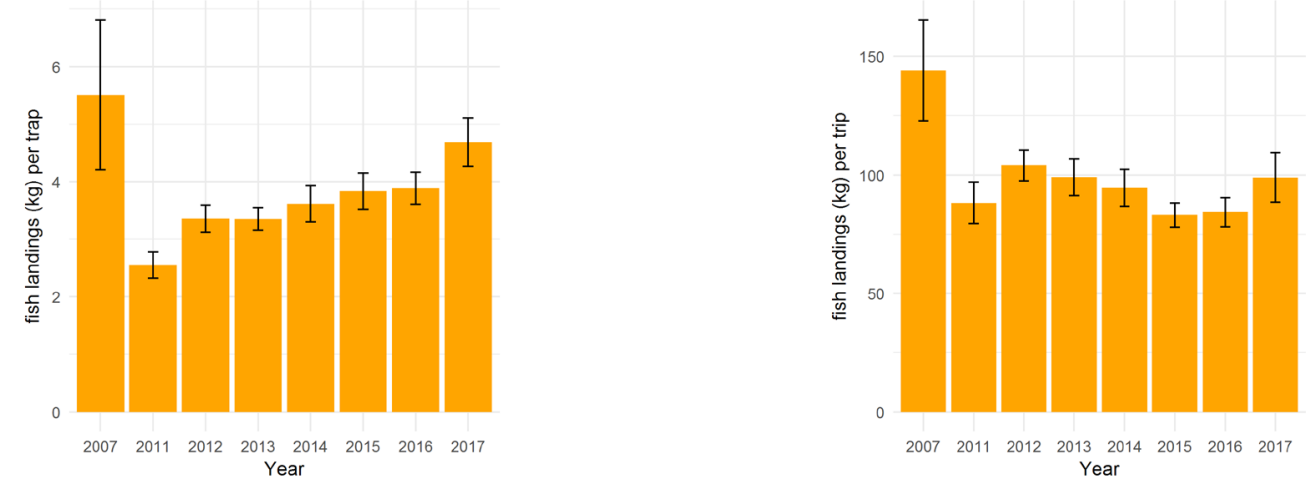

Figure 12: yearly mean catch of red fish $(\mathrm{kg})$ per trap and per trips (with $95 \%$ confidence intervals) 
The red fish catches per trip were modelled using the same approach as described for the lobster in order to estimate different effects on the catch rates and ultimately extract a standardised biomass index. Again, two models were fitted, one on the years 2011-2017 including all effects, and one on the data since 2007 , including only month, year and trap number effects.

The model fitted on the recent data shows that all effects are significant except the fishing area effect (Table 4). The difference in standardised catch per trip between vessels was larger than for lobster catches, boat with the highest catch rate catching $60 \%$ more than the boat with the lowest catch rate (Figure 13).

When fitting the model to the entire time series, the month, year and trap number effect were all significant. Some seasonality is also visible in the month effect, with low catch rates are observed between march and June, and high catch rates are observed in September/October and in February. The year effect, which is standardised biomass index for the red fish, indicates higher biomass in 2007 than the rest of the time series. The biomass index is low for 2011, and slightly higher and constant between 2012 and 2016, and increased markedly in 2017.

Table 4: significance of each model term tested by removing them one by one and comparing to the full model (GLM model of red fish catches per trip). AIC stands for Akaike information criterion (the lower the better), a p. value lower than 0.05 indicates that the effect of the corresponding factor in the model is significant.

\begin{tabular}{lllllll}
\hline Model term removed & $\begin{array}{c}\text { Number of } \\
\text { parameters }\end{array}$ & AIC & $\begin{array}{r}\text { Likelihood } \\
\text { ratio }\end{array}$ & p. value \\
\hline <none (full model) $>$ & & 1396 & & & \\
factor(Year) & 6 & 1399 & 2.43 & 0.024794 & $*$ \\
factor(Month) & 11 & 1400 & 2.34 & 0.007658 & $* *$ \\
factor(Boat_name) & 4 & 1434 & 11.33 & $6.10 \mathrm{E}-09$ & $* * *$ \\
factor(Fishing_area) & 8 & 1395 & 1.87 & 0.061766 &. \\
logTraps & 1 & 1429 & 34.35 & $6.85 \mathrm{E}-09$ & $* * *$ \\
\hline
\end{tabular}

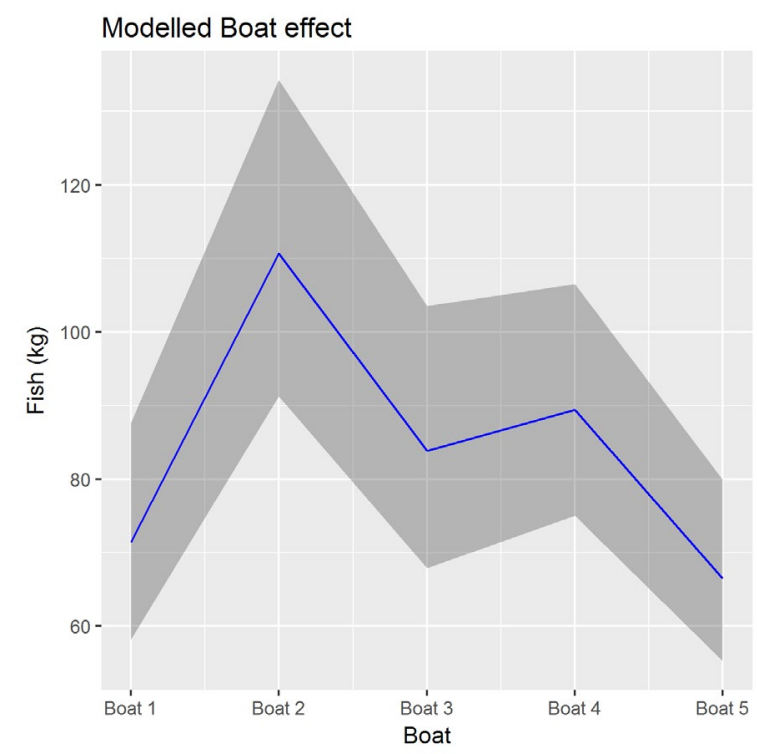



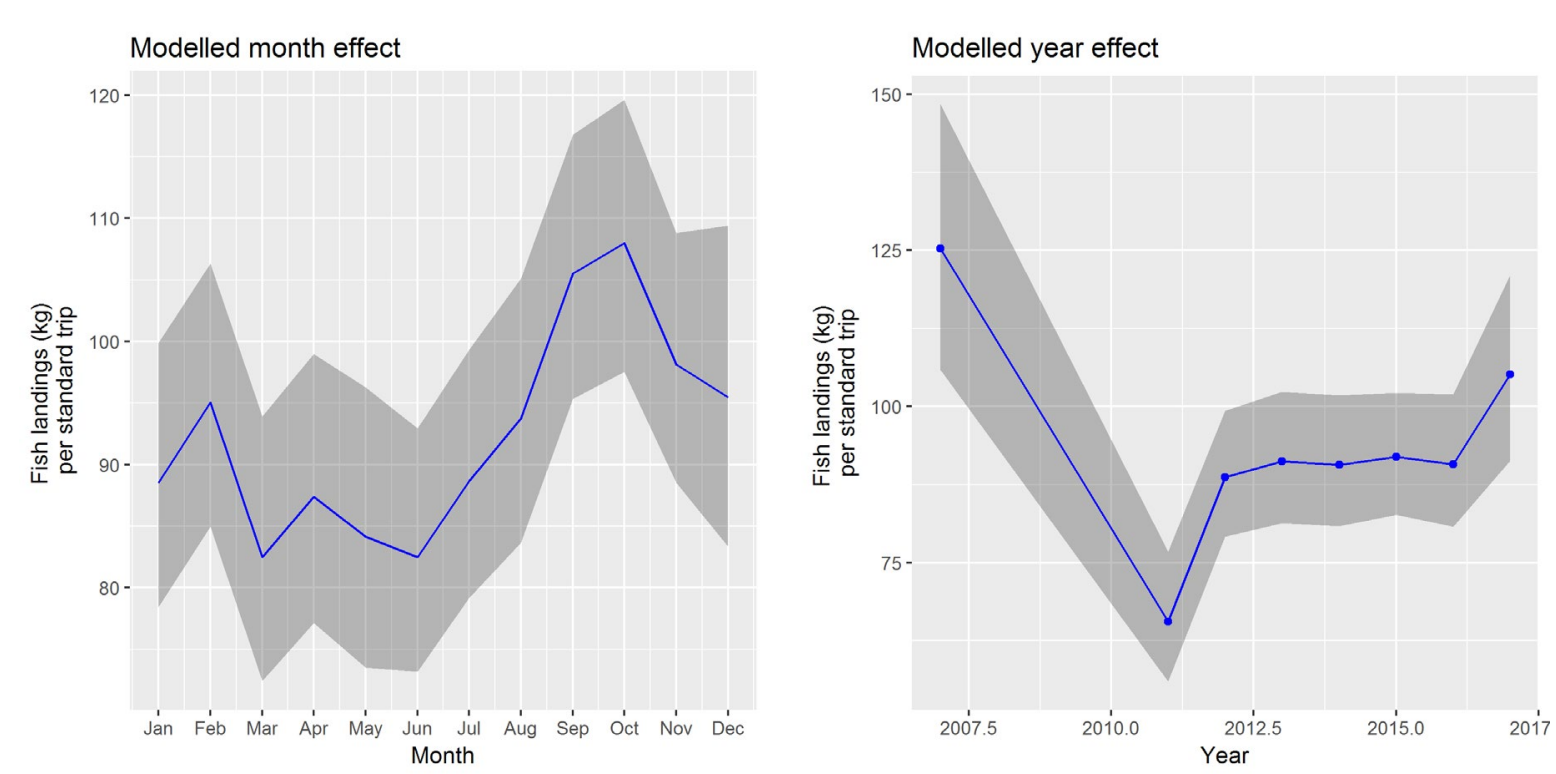

Figure 13: modelled boat effect (model fitted on the data for 2011-2017) and modelled month and year effects (model fitted on the data 2000-2017) on the catches of red fish per trips (in numbers). blue lines represent the modelled effect (and associated uncertainty in grey).

In the redfish trap fishery, the number of trips had grown significantly during the period 2012 to 2015. In 2016 effort increased again to 625 trips. In 2017 the exerted fishing effort dropped down to about 350 trips, a level seen last in 2012. The landings of redfish have fluctuated over this period, with lower values in 2012 and 2017 and higher values in 2014 and 2016 . The LPUE abundance index shows a decrease by $50 \%$ between 2007 and 2011, followed by an increase to slightly higher and constant values between 2012 and 2016, while in 2017 the LPUE abundance index continued increasing. The drop in snapper landings, despite the higher LPUE in 2017, can especially be ascribed to 6-month closed season implemented that year (Graaf et al. 2017).

\section{Landings length frequency composition}

The only species for which enough length measurements were available to have a good representation of the landings length-frequency distribution was the silk snapper (Figure 14). Since 2012, the mean length of the silk snapper landed has been slowly increasing (from $25.6 \mathrm{~cm}$ in 2012 to $28.8 \mathrm{~cm}$ in 2017). In 2017, the number of small individuals $(<23 \mathrm{~cm})$ was lower than previous years. 


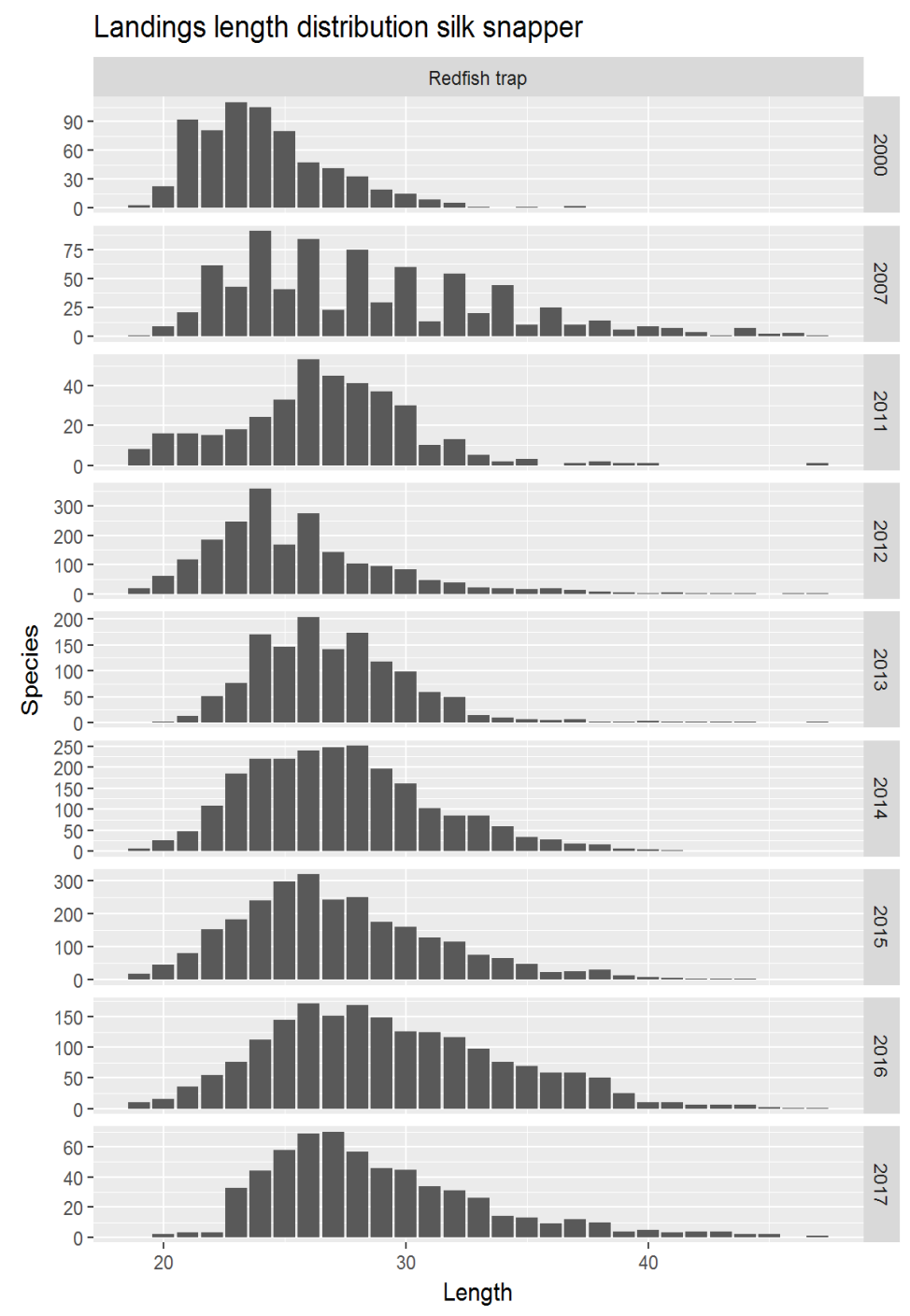

Figure 14: length frequency composition of silk snapper in redfish traps $(\mathrm{cm})$

\section{$4 \quad$ Conclusions and recommendations}

The purpose of this report was to update recent catch trends in the Saba Bank fisheries with new data from 2016 and 2017. Our overall conclusion is that for both the lobster and redfish stocks, stock status on the Saba Bank, as based on the LPUE index and size-structure of the landed catch, has continued in developing favourably. Bottom drop longline, pelagic and bycatch landings have remained much less important and have shown no significant new developments. The large drop in red fish fishing effort and catches in 2017 can largely be ascribed to the 6-month closed season that Saba fishermen chose to implement that year (April - September 2017) (Graaf et al 2017). The snapper fishing grounds used, continue to change. In 2016 and 2017 many fishermen moved their snapper traps to shallower water (Bank quadrant C4) where the lane snapper (sand silk snapper, Lutjanus synagris) is more abundant than the other snapper species.

Positive development trends in Caribbean fisheries in and by themselves are pretty unique. The developments we have documented recently for the Saba bank fisheries are quite exemplary. This may be ascribed to a cautionary management approach which is supported by the local fishermen. 
There are two matters of concern that require follow up. Firstly, the positive prognosis for the snapper "stock" status may partly be based on targeting geographically different stocks as well as different species. Hence the data as collected and analysed may actually be presenting a too optimistic assessment. To evaluate whether this is actually the case will require more detailed analysis based on individual species as well as more accurate geographical recording of catches than as currently practiced. The second matter of concern regards the fate of the traps that were in the water on the Bank when the hurricanes Irma and Maria struck the area in September 2017. The problem and challenges regarding trap loss and resulting ghost fishing have been discussed at length before (Beek 2012, Graaf et al. 2017).

Nevertheless, based on these new data we can reiterate our most recent policy assessment of cautious optimism (Debrot and de Graaf 2018). We recommend continued port sampling of catches as well as follow-up on our earlier more-detailed recommendations that may ultimately help form the basis for continued sustainable growth for the Saba Bank fisheries.

\section{$5 \quad$ Acknowledgments}

This research was financed by the Ministry of Agriculture Nature and Fisheries as part of their "BO" policy support research program with Wageningen University and Research under the project BO-43021-04-001 and project number 4318100177. We are especially grateful to Hayo Haanstra, Gelare Nader, Paul Hoetjes, and Yoeri de Vries for their support. Special thanks are due to Kai Wulf, the Saba Conservation Foundation crew and volunteers, and the Saba Bank Management Unit that generously provided facilities and logistical assistance in all aspects of the fieldwork. We thank the many college and university students and interns who contributed to the necessary data collection. Finally, we are very grateful to Karolina Molla Gazi and Jakob Asjes for their critical review.

The roles fulfilled in producing this report were as follows: T. Brunel: analysis and writing of key results; A. Kuramae and J. Odinga: data collection, field coordination and review; A. O. Debrot: project leadership and writing.

\section{References}

Beek, I. V. 2012. Lobster trap detection at the Saba Bank. Report/IMARES Wageningen UR (C091/12). Debrot, A. O. and M. de Graaf. 2018. Saba bank fisheries: reasons for cautious optimism. Wageningen Marine Research policy brief. $5 \mathrm{pp}$.

Graaf, M. de, T Brunel, L. Nagelkerke, A.O. Debrot, 2017. Status and trends Saba Bank fisheries : 2015.; Wageningen, Wageningen Marine Research (University \& Research centre), Wageningen Marine Research report C077/17. 124 pp

Stamatopoulos C (2002) Sample-based fishery surveys: a technical handbook. FAO Fisheries Technical Paper. No. 425. Rome, FAO. Pp. 132. 


\section{Quality Assurance}

IMARES utilises an ISO 9001:2008 certified quality management system (certificate number: 1873782015-AQ-NLD-RvA). This certificate is valid until 15 September 2018. The organisation has been certified since 27 February 2001. The certification was issued by DNV Certification B.V.

Furthermore, the chemical laboratory at IJmuiden has NEN-EN-ISO/IEC 17025:2005 accreditation for test laboratories with number L097. This accreditation is valid until $1^{\text {th }}$ of April 2017 and was first issued on 27 March 1997. Accreditation was granted by the Council for Accreditation. The chemical laboratory at IJmuiden has thus demonstrated its ability to provide valid results according a technically competent manner and to work according to the ISO 17025 standard. The scope (L097) of de accredited analytical methods can be found at the website of the Council for Accreditation (www.rva.nl).

On the basis of this accreditation, the quality characteristic $Q$ is awarded to the results of those components which are incorporated in the scope, provided they comply with all quality requirements. The quality characteristic $Q$ is stated in the tables with the results. If, the quality characteristic $Q$ is not mentioned, the reason why is explained.

The quality of the test methods is ensured in various ways. The accuracy of the analysis is regularly assessed by participation in inter-laboratory performance studies including those organized by QUASIMEME. If no inter-laboratory study is available, a second-level control is performed. In addition, a first-level control is performed for each series of measurements.

In addition to the line controls the following general quality controls are carried out:

- Blank research.

- Recovery.

- Internal standard

- Injection standard.

- Sensitivity.

The above controls are described in IMARES working instruction ISW 2.10.2.105. If desired, information regarding the performance characteristics of the analytical methods is available at the chemical laboratory at IJmuiden.

If the quality cannot be guaranteed, appropriate measures are taken. 


\section{Justification}

Report C083/18

Project Number: 4318100177

The scientific quality of this report has been peer reviewed by a colleague scientist and a member of the Management Team of Wageningen Marine Research

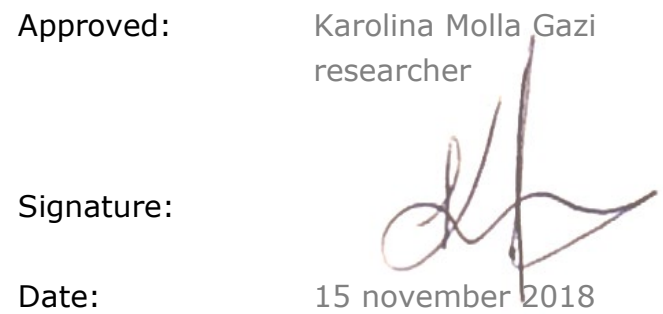

Approved: $\quad$ Drs. J. Asjes

Manager integration

Signature:

Date:

15 november 2018 
Wageningen Marine Research

T +31(0)317480900

E: marine-research@wur.nl

www.wur.eu/marine-research

Visitors' address

- Ankerpark 271781 AG Den Helder

- Korringaweg 7, 4401 NT Yerseke

- Haringkade 1, 1976 CP IJmuiden
With knowledge, independent scientific research and advice, Wageningen Marine Research substantially contributes to more sustainable and more careful management, use and protection of natural riches in marine, coastal and freshwater areas.
Wageningen Marine Research is part of Wageningen University \& Research. Wageningen University \& Research is the collaboration between Wageningen University and the Wageningen Research Foundation and its 